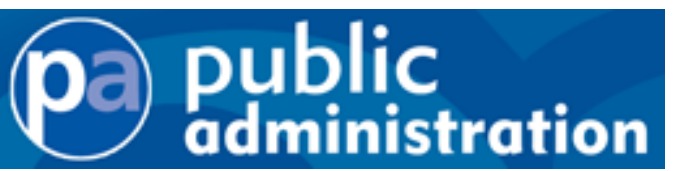

\title{
A Long and Winding Road: 25 years as editor
}

\begin{tabular}{|r|l|}
\hline Journal: & Public Administration \\
\hline Manuscript ID & PADM-21-11-00529 \\
\hline Manuscript Type: & Special Issue Article \\
\hline Keywords: & Memoir, editor, referees, specialisation, creativity \\
\hline & \\
\end{tabular}

SCHOLARONE ${ }^{\text {m }}$

Manuscripts 


\section{A Long and Winding Road: 25 years as editor}

\section{Introduction}

In October 1970, I got my first job in academia. I was a lecturer in public administration on a two-year contract at the Institute of Local Government Studies, University of Birmingham. My mentor was Richard Chapman, a keen supporter of the Royal Institute of Public Administration (RIPA). Eventually, at Richard's urging, I became a member of the RIPA, and copies of Public Administration came with membership. It has been on my bookshelves since 1972 and I edited it from 1986 to 2011.

The RIPA was a ‘mini-me' version of American Society for Public Administration. It was founded in 1922 at the instigation of the Society of Civil Servants and other staff associations (on the early years see Nottage and Stack 1972, and Nottage 1972). The first issue of the journal was published in 1923. Its contents betrayed its origins with most papers from public servants. It was a practitioner journal from the start in sharp contrast sharp with the Political Studies, the journal of the Political Studies Association of the UK (PSA), which was an academic association and journal from its formation in 1950. That practitioner streak marked the journal out as different. It was also a different world. The discipline of political science barely existed let alone a subfield of public administration. Articles were better described as essays. The academic paraphernalia of footnotes and references was optional and often missing. Refereeing was a hurdle for the future. I look back and think how much easier it was to get published back then.

The Joint University Council for Social and Public Administration, known variously as the JUC or the PAC (Public Administration Committee), started me on the journal editing road. Richard Chapman was the editor of the PAC Bulletin. When he stood down, my mentor proposed me as his successor and the PAC accepted his recommendation. I served from 
1977-82. Originally it was a newsletter rather than an academic journal and it focused on teaching public administration. Richard started to include academic articles, including a conference special issue based on the papers delivered at the PAC's annual conference. I continued this trend. I upgraded the standard of production. Previously, it had been on A4 paper with a comb binding. It was produced on a shoestring, so it was bound with staples. However, before I stood down it was bound with glue. Now it looked like every other journal. Then it seemed important! We changed the name to Public Administration Bulletin. In 1986, it became Public Policy and Administration and marketed by a commercial publisher. The journey to full journal was complete.

The journal was a perfect vehicle on which to cut my teeth as an editor because it was small enough for me to make mistakes. Every year I had to produce an annual report and present it to the JUC. Anybody could ask questions. I was acutely embarrassed when Professor Jeremy Richardson complemented me on the journal's improvement - Rhodes preens - but wished the proofreading had improved as significantly - Rhodes excoriates himself. Jeremy was correct. I was and remain an erratic proof-reader. Even worse, I persuaded Aaron Wildavsky to let me publish his paper 'Principles for a Graduate School of Public Policy'. I was thrilled. I considered it a coup until I discovered that it had been published two years earlier in the Journal of Urban Analysis (see Wildavsky 1976 and 1978). Too late. I had published it. It was strict journal policy that we did not reprint articles from other journals. I was mortified. I was cross with Aaron - he knew the rules. The brute fact was that my journal was too insignificant for it to matter. I was doubly mortified. I stood down in 1982, content I had done a decent job (Rhodes 1982).

\section{An editor's story}


I was not to know that the Public Administration Bulletin was ideal preparation for a much bigger job. In 1986, the late Christopher Pollit asked me to join him as co-editor of Public Administration. As it was the leading British journal in the field. I was delighted to accept, unaware that it would a roller coaster ride and I would remain in post for 25 years. The main differences from the Public Administration Bulletin were the quantity and quality of articles, and the support staff. We had Ivor Shelley to take care of the book reviews and we had Jean Frostick to help with all other sides of journal production. To my great relief, and no doubt to that of all the readers, I was no longer responsible for proofreading.

Under its former editor, the late Nevil Johnson, Public Administration typified traditional British public administration. It emphasised case studies, displayed a distaste for theory, and had little discussion of research methods. There were some significant changes. There was a decline in papers from the journal's established sources of the RIPA's annual conference and public lectures by senior civil servants. There were more papers by academics, and the journal's contents became less practical and more specialised (Johnson 1982)

Matters improved when Michael Lee and Christopher Pollitt took over in 1982. They made some important changes, big and small. Among the big changes, they introduced 'double blind' refereeing for the first time, themed issues, and 'Notes and Surveys' to encourage shorter pieces from practitioners. Among the small changes were the new cover and format of the journal. The seasonal labelling of issues gave way to the more formal volume and issue numbers. However, the type font on the cover remained seasonal with green for spring, red for summer, brown for autumn and, you guessed, blue for winter. Some traditions die hard. For me, the biggest innovation was their new 'statement of purpose' buried on the inside from cover of Volume 60, Issue 1, 1982. It said they would reject 
'detailed descriptions of particular administrative practices or specific organisations' unless they satisfied 'the two criteria of analytical rigour and a broad current interest' (60 (1) 1982: inside front over). This statement became my mantra when I joined Christopher as co-editor.

When Christopher stood down after six years, I became sole editor. We had agreed on so much about the journal that I expected a seamless transition. But working for the RIPA always had its challenges from the stuffiness of the grandees at council meetings to the patronising attitude of old hands when confronted with an innovation. But even by RIPA standards, my editorship of Public Administration came with an unusual challenge - the RIPA went into receivership.

The RIPA was a learned society but it was also a business. It ran courses for overseas public servants. To develop this business, it moved into a larger and more expensive property in Regents Park financed by a bank loan. Unfortunately, the London housing market was at one of its peaks and overseas recruitment was at a low. The International Division accounted for $75 \%$ of the RIPA's income. The RIPA was vulnerable to any fluctuation in recruitment to overseas courses and in consultancy income. The RIPA sold the International Division to Capita but it provided only a short respite because the bank called in both its loan and overdraft. The RIPA asked the Head of the Home Civil Service to bridge the gap but it was the heyday of Thatcherism and bailing out 'lame ducks' was a no-no. The bank called in the receivers on the $13^{\text {th }}$ July 1992 and the RIPA ceased to exist in December (for a fuller history see Rhodes 2011, Shelley 1993 and for commentary see Chapman 1993.)

A RIPA asset was the journal. It could be sold to a commercial publisher. I knew Sue Corbett at Basil Blackwell because they were the publishers of the journal. I suggested Blackwell might want to make a bid. I offered to stay on as editor and help the journal through this sticky patch. It was sticky. Most subscriptions to the journal were part of the 
membership package. No RIPA, no members, no journal subscriptions was not an attractive equation. Sue persuaded her bosses the journal was a viable proposition. Blackwell made a bid, which was accepted. To show that I was serious about saving the journal, I waived my honorarium (of several thousand pounds) and accepted a $10 \%$ royalty payment. As that was $10 \%$ of nothing, I can claim that I was not in it for the money. It was, however, one of my farther sighted financial decisions because the number of journal subscribers rose gradually from a few hundred to a few thousand. It turned into a tidy little earner. It was a case of tell the righteous it will be well with them, for they will enjoy the fruit of their deeds. Sue and Blackwell agreed as the journal's circulation, and length, grew year by year. Sue went on to become Managing Director of Wiley-Blackwell.

The change of ownership brought other changes. When owned by the RIPA, editors of the journal had to pay serious attention to the demands of practitioners. Subscriptions from the public sector provided much of the RIPA's income. No more. Corporate members did not renew their subscriptions. The new income base was academics and university libraries. Quickly, articles by and for practitioners dwindled to a rump. Public Administration became a hardcore academic journal.

The personal computer and the internet changed journal editing significantly. Historically, authors would submit three hard copies of their article and I would forward the paper with a covering letter to referees. They would reply on a referee's report form and I would write to the author with my decision including copies of the referees' reports. The RIPA paid for a secretary to help me with the correspondence - heady days! Then, almost overnight, electronic correspondence replaced paper. Papers were submitted and all correspondence was conducted through a web-based manuscript management platform. There were irritations at first. We ran the paper system alongside the electronic system, mainly 
because some colleagues did not have computers or were technophobes. Also, the early versions of the software were cumbersome compared to today's versions. But it was a good system. I could not have edited the journal when living in Australia without it. Snail mail was not only true to its name, but postage was expensive. Email was good because it cut out all the flowery, polite language used in letters. It was no longer necessary to type, 'Thank you for your letter of ...' etc. The abruptness suited me!

The heart of a journal's system are referees' reports. You must have at least two out of three reports recommending publication or minor revision for the paper to be accepted. However, daily practice is a little different. First, there is the 'desk review'; that is, the editor decides whether to send your article to a referee. I desk reviewed because we received too many case studies of specific policies that were of no general theoretical or practical interest. The stated editorial policy, published in every issue of the journal, said no case studies. I just rejected such submissions. You can also desk review to ensure an article fits the journal's template. My view was that I edited an academic journal, and I did not want to publish lectures by top civil servants or discursive essays. You would never desk review a submission from a loathed colleague or one employing a theory or method you thought cockeyed. It would be an invitation to a dispute. Much easier to let the referees take either credit or blame.

Sometimes an air of sanctity can surround referees. Editors just forward the reports to authors as if the reports are tablets of stone from Mount Sinai. Way too often they contradict one another, but there is no steer from the editor about whose advice to follow. To do that, they would have to read the paper, and many do not. I managed 350-400 submissions a year plus resubmissions. I could not, and did not, read them all, but I read all the papers that received conflicting reports. I never deliberately chose hostile referees for a paper. I chose referees whom I thought would be broadly sympathetic. I wanted to know if a paper was a 
good example of its ilk. My rule of thumb was 'what's good is good irrespective of genre'. I thought it was pointless getting a known devotee of (say) Marxist approaches to referee a paper by a believer in neoliberal ideas. In an era where peer review is the gold standard, there is a view that editors only manage the flow of papers. Not true. Editors remain powerful because they desk review, choose referees, and advise authors about those reports.

Editors must exercise quality control over referees otherwise there is the danger of 'tardy, abusive and self-serving' reports with the reviewer 'hiding behind the cloak of anonymity to put a rival down regardless of merit' (Times Higher Education 6 December 2018). It is important to avoid ego-gratifying gatekeepers or 'trusties'. Editors must edit, not just pass on reviews. Abusive remarks should be deleted and not be sent to authors. Where referees contradict one another, the editor should give a steer to the author. As someone who has refereed many a paper, I am aware of the ever-present dangers of unconscious bias, conflicts of interest, and being out-of-date with my reading. I try to be self-aware and on my guard. It is easy to avoid some dangers such as loathing a colleague - you can decline to referee. Any self-respecting journal should give authors the opportunity to identify the people they do not want to referee their paper. But ignorance is more insidious because you do not know what you do not know. At times, I thought there was a macho-air to refereeing. Referees could go out of their way to be 'hard'. I incline to the view the referees ought to be constructive critics and help to get the paper published. Too often that is not the case. Is it too outrageous to suggest that we should try to be kind? Peer review is supposed to be the gold standard of academic assessment. It may be preferable to bibliometric rankings, but it has many flaws, and it is incumbent on editors to mitigate the worst features of the system.

Desk reviewing and referees are the everyday stuff of editing. I make it sound as if it is a passive role, reacting to submissions as they come in. Nevil Johnson (1982:131) opined 
that 'an editor remains highly dependent on the people who are writing and his (sic) scope for shaping the general character of the contributions offered is rather limited' (Johnson 1982: 131). Such conservative passivity did not appeal to me. I had a more proactive view of my role. I responded to changing fashions in the profession. No editor worth his or her salt could ignore the growth of the new public management and we introduced a separate 'Public Management' section in 1992 with its own deputy editor. Similarly, we introduced a 'European Form' in 1999, again with its own deputy editor, to encourage submissions from and about European public administration. I also encouraged submissions from groups of colleagues whom I thought were doing interesting work. Thus, over the years, I supported work in my own areas of interest such as policy networks, governance, and interpretive public administration as well as areas in which I did not work such as consumerism, streetlevel bureaucrats, and Chinese public administration. I did so by encouraging seminar paper givers, workshop directors and conference organisers to think about editing a symposium in, or special issue of, the journal. I never saw myself as a paper pusher, and I think it made a difference to the breadth of the journal's contents (Needham 2016: 346). I made sure I had scope to shape the general character of contributions to the journal.

\section{Some bugbears}

There are all too many commentaries on trends in journal publishing. On standing down as editor, I essayed my own list in Rhodes (2011: 6-8) where I discussed the impact on journals of the professionalisation of political science; the corporatisation of British universities and their auditing regimes; the increasingly sophisticated marketing strategies of publishers; the internationalisation of the journal; and the digitisation of journals. Since then, we have had the rise of open access journals; the digitisation of the book with web-based publication not only of books but of individual chapters; and, boosted by Covid-19 
lockdowns, new ways of interacting with colleagues through Zoom, MS Teams, Researchgate, and other platforms. All are important but this paper is more a memoir than an academic article. So, I prefer to take the opportunity to air some of my pet bugbears rather than add to the growing literature on the future of the journal.

Journals are not just about the CVs of authors or the profits of the publisher. They are also the carriers of a subject's traditions. A long-standing feature of political science and by extension public administration is the key role of books in passing on the traditions. We arrive at bugbear \#1 - the downgrading of books.

The book review section of Public Administration is in an increasingly parlous state containing at best a couple of reviews each issue and none in special issues. Even worse, Political Studies Review, the book review journal of the PSA, now no longer publishes reviews! Yet, books remain the most prestigious academic output. To quote the REF Panel (2015: 79) 'authored books ... were most likely to be judged world-leading' and The Panel reaffirmed 'the need to maintain and defend the crucial role of the research monograph in the discipline.' For this former editor, a key mission of Public Administration is to foster the discipline as a whole and engaging with book publication is part of that mission. The journal needs to reinvent the book review for the era of social media.

It was my experience that colleagues were increasingly reluctant to review books. Yet many became ardent bloggers. I suggest introducing a journal blog to which anyone can contribute a book review. The editor of that section's job would be to encourage contributors and ensure that reviews did not fall foul of the common social media excesses. The publishers' role would be to provide the website and electronic copies of books. A model would be the reviews of records on allmusic.com. 
Bugbear \#2 is the hyper-specialisation of the subject. As Kagan (2009: 257 and 260) observes we live in an era 'with an extreme degree of specialisation' and as a result we get a stream of narrow, technical papers that have 'neither practical utility nor theoretical significance' (Kagan 2009: 257 and 260). His sentiments were echoed by the REF Panel (2014: 79) which concluded that for articles there was 'an almost step-level increase in rigour' nonetheless such rigour did not necessarily produce 'work judged to attain a similar international standard in terms of originality and significance'. In short, form dominated substance, specialisation prevailed over breadth of vision. Again, the journal can do something to counteract such trends. A proactive editor can encourage brainstorming by the editorial board to identify Big-C contributors; that is 'the remarkable and lasting contributions made by mavericks in some domain' (Kaufman and Beghetto 2009: 2). The challenge for the editor is to find the mavericks, the Big-C contributors, and turn them loose.

Bugbear \#3 is the article template. Increasingly research is 'mainstreamed'. We are creating '\#newbreed political scientist'. The new generation are not only technically proficient and substantively narrow, but they are also encouraged to write journal articles, not books, and to follow set templates for such articles. A typical format would stipulate an introduction, a review of literature, a description of research methods, the findings, a discussion of the findings, conclusions, references, and appendices (if needed).

Such templates are confining. For example, if you are reporting ethnographic fieldwork that relies on a thick description of people and events, you have only one section in which to provide it. Too much space is taken up with what other people have said (the literature review and references) and with how you did it (methodology and appendices), not with what you did (findings and discussion). There is nothing mere about description - it is fundamental to any analysis (Gerring 2012). So, the template is a straitjacket, and it lies at the 
heart of mainstreaming. It is hard to believe the greats of the social sciences would conform to them. Some of Max Weber's sentences are article length! Under this regime, it is hard to believe there will be greats ever again. We need to encourage eclecticism, not impose conformity.

Of course, it is easy for established professors to rant on about what irritates them. We are no longer building careers. We do not have to please promotion and selection committees. On looking back on his 'conventional career', Lindblom (1988: 19) noted that his career involved 'some prudent adaption to its milieu, a confining set of disciplinary traditions, and a willingness to disregard them growing only slowly with age and security'. I too was prudent, but I also pushed back against disciplinary traditions when I could do so. My bugbears identify opportunities for future editors of the journal to push back by supporting the prestige of the book, Big-C creativity, and iconoclastic articles.

The backcloth to my bugbears is not trends in Public Administration but trends in the field at large. There is a template for political science and public administration as well as for journal articles. It prioritises quantitative work, causal inference, and formal models. There is little space for interpretive work in most political science departments. So, underpinning my plea to support book publication, Big-C creativity, and eclecticism is a plea to resist templates wherever we may find them. For aeons, we have understood that strength lies in diversity not similarity. We need to practice eclecticism and iconoclasm in public administration. 


\section{References}

(1982), From the Editors. Public Administration, 60: 1-2.

(1999) 'Editorial: Public Administration in Europe' Public Administration 77 (1): 1-6.

Chapman, Richard, A. (2008) 'The Demise of the RIPA — An Idea Shattered' Australian Journal of Public Administration 52:466 - 474.

Gerring, J. (2012) 'Mere description.' British Journal of Political Science 42: 721746.

Johnson, N. (1981) 'Editorial: Writing about Public Administration — the Search for Common Ground'. Public Administration, 59: 127-138.

Kagan, J. (2009) The Three Cultures. Natural Sciences, Social Sciences and the Humanities in the $21^{\text {st }}$ Century. Revisiting C.P. Snow. Cambridge: Cambridge University Press.

Kaufman, J. C. and Beghetto, R. A. (2009) 'Beyond Big and Little: The Four C Model of Creativity', Review of General Psychology 13(1): 1-12.

Lindblom, C. E. (1988) Democracy and the Markey System. Oslo: Norwegian University Press.

Needham, Catherine (2015) ‘Public Administration’ In Mark Bevir and R. A. W. Rhodes (Eds.) Routledge Handbook of Interpretive Political Science. Abingdon: Routledge, pp. 338-351.

Nottage, R. and Stack, F. (1972) 'The Royal Institute of Public Administration 19221939’. Public Administration, 50: 281-304. 
Nottage, R. (1972) 'The Royal Institute of Public Administration 1939-1972'. Public Administration, 50: 419-443.

Research Excellence Framework (2014) Overview Report by Main Panel C and Subpanels 16 to 26. Available @: https://www.ref.ac.uk/2014/panels/paneloverviewreports/. Last accessed 8 November 2021.

Rhodes, R. A. W. (1982) 'Plus ca change, plus c'est la meme chose: an exercise in editorial nostalgia' Public Administration Bulletin No. 38 August: 2-7.

Rhodes, R. A. W. (2011) 'Yesterday When I was Young'. In R. A. W. Rhodes, Ed., Public Administration: 25 years of analysis and debate, 1986-2011. Oxford: WileyBlackwell, pp. 1-16.

Shelley, Ivor (1993) 'What happened to the RIPA?' Public Administration 71: 47189.

Wildavsky, A. (1976) 'Principles for a Graduate School of Public Policy', Journal of Urban Analysis, 3 (1): 127-52. Reprinted in Public Administration Bulletin, No. 26 April: $12-31$. 